\title{
The impact of applications of sugar cane filter cake and vinasse on soil fertility factors in fields having four different crop rotations practices in Brazil
}

\section{Impacto das aplicações de torta de filtro e vinhaça de cana-de-açúcar sobre fatores de fertilidade do solo em áreas tendo quatro diferentes práticas de rotações de cultura no Brasil}

\author{
Livia Lima CAMPITELI'; Roberta Mendes SANTOS²; George LAZAROVITS ${ }^{3}$; Everlon Cid RIGOBELO \\ ${ }^{1}$ Mestre em Microbiologia Agropecuária - Programa de Pós- Graduação em Microbiologia da Univ. Estadual Paulista UNESP \\ Campus de Jaboticabal, livialis@gmail.com \\ ${ }^{2}$ Mestre em Microbiologia Agropecuária - Programa de Pós-Graduação em Microbiologia da Univ Estadual Paulista UNESP \\ Campus de Jaboticabal, santos-rm@outlook.com \\ ${ }^{3}$ Diretor da Alcanada London Ontário Canadá, lazarovitsg@alcanada.ca \\ ${ }^{4}$ Autor para Correspondência" Prof. Dr. Departamento de Produção Vegetal da Univ. Estadual Paulista UNESP Campus de \\ Jaboticabal, everlonnsms@fcav.unesp.br
}

Recebido em: 06-04-2017; Aceito em: 22-08-2017

\begin{abstract}
In this study we examined how the use of vinasse and filter cake as fertilizers at four different sites alters crop yields of sugarcane. The objective was to determine the impacts based on the products fertility and to identify if and how the treatments altered soil microbiology. Using an untreated site as a control (treatment 1) we compared the effect on various soil parameters at sites where soybean was planted after cane production (treatment 2) using just chemical fertilizer, a site which received vinasse as a fertilizer during the sugarcane crop at levels that allowed for replacement of chemical $\mathrm{K}_{2} \mathrm{O}$ (treatment 3 ) and a site which received filter cake as a replacement of $\mathrm{P}_{2} \mathrm{O}_{5}$ (treatment 4). When all four sites were compared, organic matter was highest at sites amended with filter cake $(19.8 \%)$ whereas, moisture levels were highest at the vinasse treated sites (18.9\%). The phosphorus concentration was also the highest with filter cake amendment. The yields of sugarcane from the control and above described treatments did not differ each other. These findings suggest that vinasse and filter cake improve soil microbiological and fertility conditions although the changes here were not reflected in the yields of sugarcane crop obtained.
\end{abstract}

Additional keywords: soil bacteria; soil microbiology; sugarcane.

\begin{abstract}
Resumo
Neste estudo, examinou-se como o uso da vinhaça e da torta de filtro como fertilizantes em diferentes áreas altera a produção de cana-de-açúcar. O objetivo foi determinar o impacto baseado na fertilidade e identificar se e como os tratamentos alteraram a microbiota do solo. Usando uma área não tratada como um controle (Tratamento 1) comparou-se o efeito de vários parâmetros de solo nas áreas onde soja foi plantada depois da produção de cana (Tratamento 2), usando apenas fertilizante químico, uma área que recebeu vinhaça como fertilizante durante a cultura da cana em níveis que permitiram a reposição de nutriente químico potássio $\mathrm{K}_{2} \mathrm{O}$ (Tratamento 3) e uma área que recebeu torta de filtro como reposição de $\mathrm{P}_{2} \mathrm{O}_{5}$ (Tratamento 4). Quando todos os quatro foram comparados, a matéria orgânica foi maior nas áreas alteradas com torta de filtro (19,8\%), enquanto, os níveis de umidade foram maiores nas áreas tratadas com vinhaça (18,9\%). A concentração de fósforo também foi maior com a alteração com torta de filtro. As produtividades da cana-de-açúcar do controle dos tratamentos descritos acima não diferiram entre si. Esses resultados sugerem que a vinhaça e a torta de filtro podem melhorar as condições microbiológicas e a fertilidade do solo, apesar de as mudanças não terem refletido na produtividade da cultura da cana-de-açúcar.
\end{abstract}

Palavras-chave adicionais: bactéria do solo; cana-de-açúcar; microbiologia do solo.

\section{Introduction}

Brazil being the world's largest producer of sugarcane has an enormous volume of bio-waste that is generated after processing in the form of vinasse, the residual liquid remaining from the fermentation of the sugar extract into alcohol, and filter cake, which is mostly cellulosic material remaining after the sugar is extracted from the cane. The vinasse is often used for fertigation (Christofoletti et al., 2013) by the infiltration of raw vinasse into the soil through irrigation systems prior to planting the sugarcane crops (Camargo et al., 2009). Using vinasse as fertilizer reduces the cost of production as lower amounts of chemical fertilizers are 
applied (Laime et al., 2011). Filter cake is composed of a mixture of ground bagasse and mud/sludge derived from the sugar clarification process. For each ton of ground sugarcane utilized, 30 to $40 \mathrm{~kg}$ of cake is produced. Filter cake is mainly applied as a fertilizer in the sugarcane-planting furrow (Adorna et al., 2013).

Vinasse and filter cake both act as rich sources of nutrients for the growth of soil microorganisms and adding these products to soil has been shown to significantly impact their populations (Adorna et al., 2013). This in turn affects the soil composition in terms of the rates of $\mathrm{C}, \mathrm{N}$, and $\mathrm{P}$ mineralization (Pupin \& Nahas, 2011).

With the increase cost of synthetic fertilizers and the need to recycle the large quantities of organic residues in a sustainable manner, there is increasing interest in using this resource for agriculture. Filter cake and vinasse are recognized low cost materials and are considered to be able to improve soil fertility and plant productivity (Prado et al., 2013).

The application of filter cake and vinasse naturally affects many soil parameters. However, the nature of this impact on the soil microbiota has not been studied to date. In this study, we examined four sugarcane production sites receiving distinct biological fertilizer treatments and crop rotations (vinasse, filter cake, soybean, and a chemical fertilizer control) and analyzed the organic matter, soil moisture, number of colony unit forming cells, microbial biomass $\mathrm{C}$, respiratory activity, $\mathrm{P}$ solubilizing bacteria, ammonium concentration, nitrate concentration and soluble phosphorus concentration. Results are discussed in terms of the advantages and disadvantages of each of these methods in terms of microbiological and chemical soil parameters.

\section{Material and methods}

The experimental site is located in Frutal-MG state with altitude of $550 \mathrm{~m}$. The soil type for all areas is Eutrustox and the climate, according to Köppen, is classified as Cwa, with hot summers and dry winters. The mean annual temperature is $21^{\circ} \mathrm{C}$ and the average rainfall is $1,428 \mathrm{~mm}$. All areas are located near sugarcane producing farms and are in the same environmental conditions.

\section{Description of treatments}

The experiment was carried out in four areas. Each area was divided in five plots. Each plot had 75 $\mathrm{m}^{2}$ with five rows of sugarcane with 10 meters of length and spacing $1.5 \mathrm{~m}$ between rows. Useful area was considered as being the three rows from each plot discarding $1 \mathrm{~m}$ from each extremity.

The soil samples were collected in four areas of a farm where sugarcane production was under very different rotations and fertility management with each area receiving very different fertilization treatments over the last five years. The first area (control) was planted with only with sugarcane during five years without any rotation crops. It was fertilized with chemi- cal fertilizers at rates set out by soil analysis recommendations. The second area (soybean) was planted with soybeans after cane production and it also received chemical fertilizers according to soil analysis recommendations. The third area (vinasse) received vinasse as a fertilizer during the sugarcane crop at levels that allowed for replacement of chemical $\mathrm{K}_{2} \mathrm{O}$. Other nutrients were added as chemical fertilizers according to chemical analysis of soil recommendations. The fourth area (filter cake) received filter cake as a replacement of $\mathrm{P}_{2} \mathrm{O}_{5}$ along with chemical fertilizers according to chemical analysis of soil recommendations. While both vinasse and filter cake were added primarily to reduce the use of amount of $\mathrm{K}_{2} \mathrm{O}$ and $\mathrm{P}_{2} \mathrm{O}_{5}$ fertilizers, respectively, they also brought other fertility contents to the soil.

The amount of vinasse and filter cake applied is based on soil analysis therefore the amount varies with each crop year. The vinasse was transferred to area by truck and was then applied using a hydraulic cannon. The dose of vinasse utilized was from 200 to $300 \mathrm{~m}^{3}$ per year. The filter cake was incorporated in soil during the sowing using a cart. The dose of filter cake incorporated ranged from 40 to 60 ton/ha. Soybean is typically used as a rotation every five years.

\section{Yields of sugar cane}

For the cane sampling, ten culms were randomly collected from useful area from each site one week before the cane harvest. The culms production were measured by weighing of culms from useful area taken at sampling. The yield from each area was expressed at $\mathrm{t} \mathrm{ha}^{-1}$.

\section{Soil samples}

Samples of Eutrustox Soil were randomly collected during the winter months of June-July in all areas. Each sample consisted of six sub-samples taken from $0-20 \mathrm{~cm}$ soil depth. The samples were collected with aids of a soil probe. The samples collected were transferred to a bucket, homogenized and approximately $400 \mathrm{~g}$ was transferred to a plastic bag and transported to the laboratory. Each of the four areas was divided into five plots, with 30 samples being collected per plot, totaling 150 samples. Soil samples were transported to the laboratory, sieved $(2 \mathrm{~mm})$ and homogenized. Each sample was divided into two parts: one part was kept at $7 \stackrel{\circ}{\circ} \mathrm{C}$ until analysis and the other part was air-dried and stored at room temperature.

\section{Microbiological and physical analysis}

Organic matter was determined after the addition of potassium dichromate-sulfuric acid to the soil samples (Sims \& Haby, 1971). The moisture content was determined by drying the soil at $105^{\circ} \mathrm{C}$ until a constant weight was reached. The chemical composition of the soil from each area was determined at the Soil Analysis Laboratory of the Department of Soils and Fertilizers, UNESP/Jaboticabal (Table 1). 
Table 1 - Chemical properties of soils from four areas with different fertilization systems.

\begin{tabular}{llcccc}
\hline Attributes & & Control & Soybean & Vinasse & $\begin{array}{c}\text { Filter } \\
\text { Cake }\end{array}$ \\
\hline $\mathrm{pH}$ & $\left(\mathrm{CaCl}_{2}\right)$ & 6.1 & 5.0 & 5.6 & 6.4 \\
Organic matter & $\left(\mathrm{g} \mathrm{dm}^{-3}\right)$ & 34 & 23 & 35 & 77 \\
$\mathrm{P}$ resin & $\left(\mathrm{mg} \mathrm{dm}^{-3}\right)$ & 24 & 35 & 9 & 1024 \\
$\mathrm{~K}^{+}$ & $\left(\mathrm{mmol}_{\mathrm{c} \mathrm{dm}}^{-3}\right)$ & 1.3 & 1.4 & 6.4 & 6.8 \\
$\mathrm{Ca}^{+}$ & $\left(\mathrm{mmol}_{\mathrm{c} \mathrm{dm}}^{-3}\right)$ & 137 & 31 & 58 & 239 \\
$\mathrm{Mg}^{2+}$ & $\left(\mathrm{mmol}_{\mathrm{c}} \mathrm{dm}^{-3}\right)$ & 62 & 7 & 25 & 78 \\
$\mathrm{H}^{+}+\mathrm{Al}^{3+}$ & $\left(\mathrm{mmol}_{\mathrm{dm}}^{-3}\right)$ & 15 & 28 & 28 & 15 \\
Sum of bases, SB $(\mathrm{K}+\mathrm{Ca}+\mathrm{Mg})$ & $\left(\mathrm{mmol}_{\mathrm{c} \mathrm{dm}}^{-3}\right)$ & 200.3 & 39.4 & 89.4 & 323.8 \\
Cation exchange capacity, $\mathrm{T}(\mathrm{SB}+\mathrm{H}+\mathrm{Al})$ & $\left(\mathrm{mmol}_{\mathrm{c} \mathrm{dm}}^{-3}\right)$ & 215.3 & 67.4 & 117.4 & 338.8 \\
Soil base saturation $[(\mathrm{SB} / \mathrm{T}) \times 100)]$ & $(\%)$ & 93 & 58 & 76 & 96 \\
\hline
\end{tabular}

The chemical composition of the filter cake and vinasse are shown at Tables 2 and 3 .

Table 2 - Concentrations of organic matter, mineral elements, $\mathrm{pH}$ values and $\mathrm{C} / \mathrm{N}$ ratios determined in filter cake calculated on dry weight basis.

\begin{tabular}{lc}
\hline Determinations & Filter cake (means) \\
\hline Organic matter (\%) & 22.6 \\
$\mathrm{pH}$ & 7.3 \\
$\mathrm{~N}(\%)$ & 2.3 \\
$\mathrm{P}(\%)$ & 1.6 \\
$\mathrm{~K}(\%)$ & 0.6 \\
$\mathrm{Ca}(\%)$ & 2.7 \\
$\mathrm{Mg}(\%)$ & 0.8 \\
$\mathrm{~S}(\%)$ & 0.28 \\
$\mathrm{C} / \mathrm{N}$ ratio & 27 \\
\hline
\end{tabular}

Table 3 - Chemical requirements for oxygen (CRO), biological requirements for oxygen (BRO), electrical conductivity (EC), total dissolved solids (TDS), $\mathrm{pH}$ values, sodium and macronutrient concentrations of vinasse.

\begin{tabular}{lc}
\hline Determinations & Vinasse (Means) \\
\hline CRO $\left(\mathrm{mg} \mathrm{L}^{-1}\right)$ & 32.31 \\
$\mathrm{BRO}\left(\mathrm{mg} \mathrm{L}^{-1}\right)$ & 12.12 \\
$\mathrm{EC}(\mathrm{dS} \mathrm{L}-1)$ & 9.35 \\
$\mathrm{TDS}\left(\mathrm{mg} \mathrm{L}^{-1}\right)$ & 12.12 \\
$\mathrm{pH}$ & 4.9 \\
$\mathrm{~N}\left(\mathrm{mg} \mathrm{L}^{-1}\right)$ & 482 \\
$\mathrm{P}\left(\mathrm{mg} \mathrm{L}^{-1}\right)$ & 179 \\
$\mathrm{~K}\left(\mathrm{mg} \mathrm{L}^{-1}\right)$ & 1.67 \\
$\mathrm{Na}\left(\mathrm{mg} \mathrm{L}^{-1}\right)$ & 201 \\
$\mathrm{Ca}\left(\mathrm{mg} \mathrm{L}^{-1}\right)$ & 512 \\
$\mathrm{Mg}\left(\mathrm{mg} \mathrm{L}^{-1}\right)$ & 132 \\
\hline
\end{tabular}

Microbial respiratory activity (MRA) was determined by incubating moist soil (100 g dry soil) with $20 \mathrm{ml}$ water and $20 \mathrm{ml}$ of $0.5 \mathrm{M} \mathrm{NaOH}$ in $2.5-\mathrm{L}$ jars, which were sealed and incubated for 12 days at $30{ }^{\circ} \mathrm{C}$ in darkness (Resende et al., 2006). The $\mathrm{CO}_{2}$ evolved was determined by titrating the remaining $\mathrm{NaOH}$ solution with $1 \mathrm{M} \mathrm{HCL}$ using phenolphthalein indicator

$P$ solubilizing bacteria were identified by incubating $10 \mathrm{~g}$ soil with peptone water $0.9 \%$ and shaking for 10 minutes. Then an aliquot was transferred to Bunt and Rovira medium with addition of $38.4 \mathrm{mg}$ fluorapatite $\mathrm{g}^{-1}$ dry soil for one week at $30^{\circ} \mathrm{C}$. After that the presence of halo on the plate was verified every day. All strains that presented halo on the plate were counted as $\mathrm{P}$ solubilizing bacteria.

Ammonium and nitrate were determined using the indophenol blue method according to (Keeney \& Nelson, 1982).

Phosphorus concentrations were determined using a spectrophotometer by the ascorbic acid method (Watanabe \& Olsen, 1965) following the wet digestion procedure. Available phosphate was determined colorimetrically following a sodium bicarbonate extraction at pH 8.5 (Olsen \& Sommers, 1982).

\section{Experimental design}

The experimental design was a split plot with four systems of fertilizers (soybean, vinasse, filter cake, and only chemical fertilizer as control) with five replicates each. The $\mathrm{F}$ test was used for analysis of variance of the results and the Tukey test at $5 \%$ probability was used to compare means of treatments. All statistical analysis were made in the Sigmaplot 11.0 program. Table 1 shows the chemical properties from four areas.

The concentrations of organic matter, mineral elements, $\mathrm{pH}$ values, and $\mathrm{C} / \mathrm{N}$ ratios determined in filter cake calculated on dry weight basis are depicted in Table 2, and Table 3 shows chemical requirements for oxygen (CRO), biological requirements for oxygen (BRO), electrical conductivity (EC), total dissolved solids (TDS), $\mathrm{pH}$ values, sodium, and macronutrient concentrations of vinasse.

\section{Results}

\section{Chemical analysis of four areas with different} fertilization methods

Relative to all other areas, the area that received filter cake presented higher values for $\mathrm{P}$ $\left(1024 \mathrm{mg} \mathrm{dm}^{-3}\right), \mathrm{Mg}^{2+}\left(239 \mathrm{mg} \mathrm{dm}^{-3}\right)$, sum of bases (323.8 $\mathrm{mmol} \mathrm{L} \mathrm{dm}^{-3}$ ), and cation exchange capacity (Table 1). The filter cake area was also significantly higher than the other areas in terms of fertility.

\section{Yields from each area}

The yields from first, second, third and fourth areas were $125.7,124.5,125.6$, and $126.5 \mathrm{t}$ of sugarcane per hectare respectively. 


\section{Organic matter}

The organic matter concentration from each area was found to range from $4.6 \%$ (soybean) to $19.8 \%$ (filter cake). Relative to control, filter cake showed an increase of $61.4 \%$ and vinasse showed an increase of $11.1 \%$. In contrast, soybean showed a reduction of $62.9 \%$ (Figure $1 \mathrm{a}$ ).

The percentage of soil moisture was different for each area: vinasse was the highest (18.9\%), followed by filter cake (15.4\%), control (14.3\%), and soy- bean (6.3\%). All soil moisture levels were statistically different from each other (Figure 1b).

\section{Number of colony forming units}

The number of colony forming unit (CFU) cells to total bacteria ranged from $\log _{10} 7.19$ to $\log _{10} 7.41$. However, no significant differences in total bacteria were observed between areas (Figure 1c).
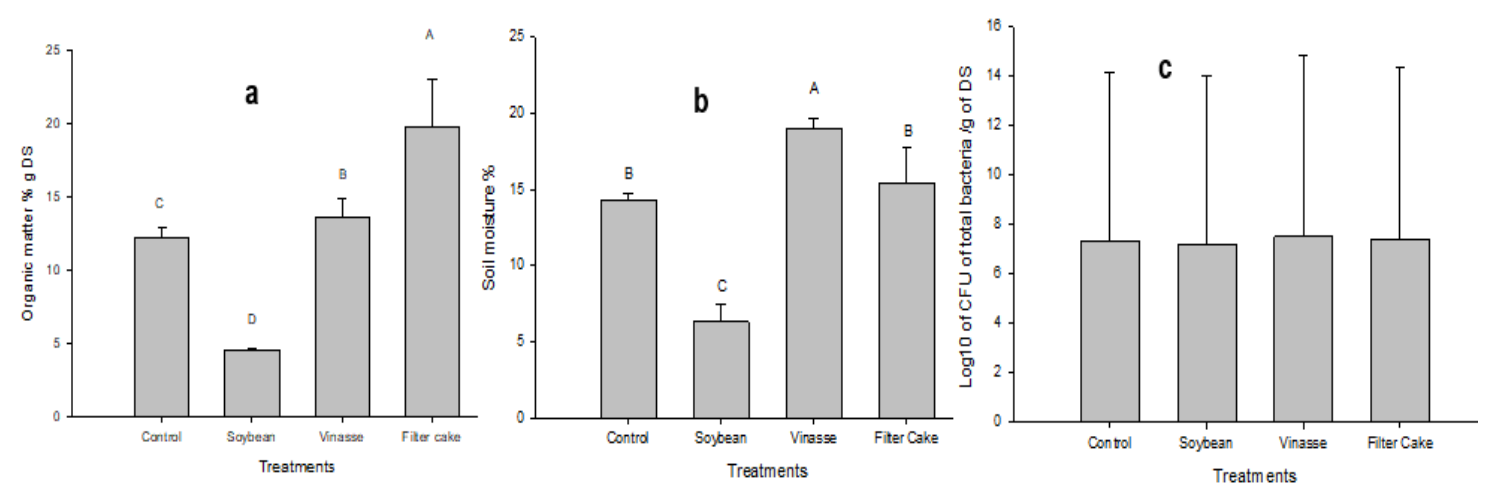

Figure 1 - Percentage (mean and standard deviation) of organic matter per gram of dry soil from soil submitted to four treatments. Each method was compared to all other methods, and all comparisons were significantly different (a); Percent soil moisture from four different soil treatments (b); Number of colony unit-forming cells per g of dry soil (c). Different letters indicate statistical significance at $P<0.05$.

\section{Microbial biomass C}

The microbial biomass $C$ value was highest for filter cake $(916.7 \mu \mathrm{g} \mathrm{C} / \mathrm{g} \mathrm{DS})$, followed by vinasse (312.8 $\mu \mathrm{g} \mathrm{C} / \mathrm{g})$, soybean $(201.3 \mu \mathrm{g} \mathrm{C} / \mathrm{g})$, and control $(132.8 \mu \mathrm{g} \mathrm{C} / \mathrm{g})$. The increase of microbial biomass C from filter cake was five times higher compared with control (Figure 2a).
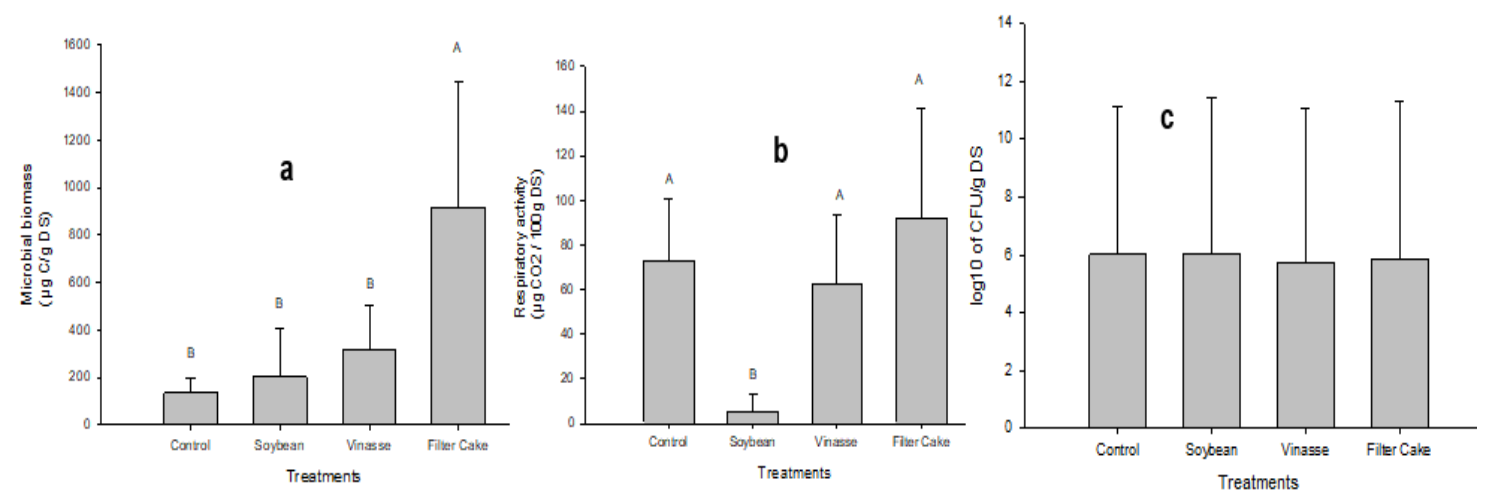

Figure 2 - Microbial biomass C (mean and standard deviation) from soil from different treatments (a); Respiratory activity of soil from different treatments (b); P solubilizing bacteria from soil from four treatments (c). Different letters indicate statistical significance at $\mathrm{P}<0.05$.

\section{Respiratory activity}

The microbial respiratory activity was highest for filter cake (92.1 $\mu \mathrm{g} \mathrm{CO} / 100 \mathrm{~g} \mathrm{DS})$, followed by control $\left(72.9 \mu \mathrm{g} \quad \mathrm{CO}_{2} / 100 \mathrm{~g} \quad \mathrm{DS}\right)$, vinasse $(62.7 \mu \mathrm{g}$ $\left.\mathrm{CO}_{2} / 100 \mathrm{~g} \mathrm{DS}\right)$, and soybean (5.2 $\left.\mu \mathrm{g} \mathrm{CO}_{2} / 100 \mathrm{~g} \mathrm{DS}\right)$. Only the respiration value measured with the soil used for soybean production was statistically significant from all other values in the various soils (Figure 2b).

\section{P solubilizing bacteria}

The number of $\mathrm{P}$ solubilizing bacteria detected was higher for soybean $\left(\log _{10} 6.03\right)$, followed by control $\left(\log _{10} 6.01\right)$, filter cake $\left(\log _{10} 5.84\right)$, and vinasse $\left(\log _{10}\right.$ 5.73). However, none of the values found were statistically different from each other (Figure 2c). 


\section{Ammonium concentration}

The ammonium concentration was highest for filter cake $\left(68 \mu \mathrm{g} \mathrm{NH}_{4}+\mathrm{g} \mathrm{DS}\right)$, followed by soybean (61 $\mu \mathrm{g} \mathrm{NH}_{4}{ }^{+} / \mathrm{g} \mathrm{DS}$ ), vinasse (57 $\mu \mathrm{g} \mathrm{NH}_{4} / \mathrm{g}$ DS), and control (54 $\mu \mathrm{g} \mathrm{NH}_{4}+\mathrm{g}$ DS). The concentration of ammonium in filter cake soil was statistically different from that of soil treated with vinasse. However, no significant differences were observed between vinasse and soybean. Finally, the ammonium concentration for the control condition was statistically different from all other treatments (Figure 3a).
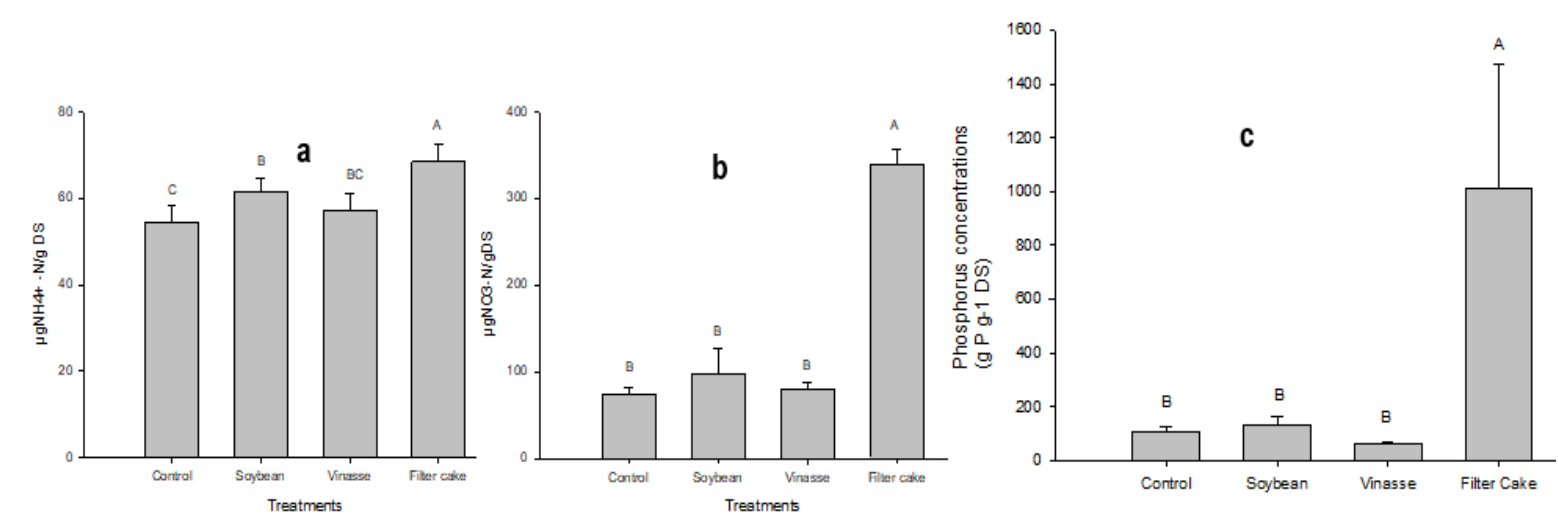

Figure 3 - Amount of $\mu \mathrm{gNH} 4^{+}-\mathrm{N} / \mathrm{g}$ DS (mean and standard deviation) from different treatments (a); NO3 amount from four areas with different treatments (b); Phosphorus concentrations from different soil treatments (c). Different letters indicate statistical significance at $P<0.05$.

\section{Nitrate concentration}

The nitrate concentration was highest in soil treated with filter cake $\left(339 \mu \mathrm{g} \mathrm{NO}{ }_{3} / \mathrm{g} \mathrm{DS}\right)$, followed by soil from the soybean plots $\left(97 \mu \mathrm{gO}_{3} / \mathrm{g} \mathrm{DS}\right)$, vinasse $\left(797 \mu \mathrm{g} \mathrm{NO}{ }^{-} / \mathrm{g} \mathrm{DS}\right)$, and control $\left(73 \mu \mathrm{g} \mathrm{NO}{ }_{3} / \mathrm{g} \mathrm{DS}\right)$. Filter cake was the only treatment that differed significantly from all others in its nitrate content (Figure $3 b$ ).

\section{Phosphorus concentration}

The phosphorus concentration was highest for filter cake area (1011 $\left.\mathrm{g} \mathrm{P} \mathrm{g}^{-1} \mathrm{DS}\right)$, followed by soybean (133 $\mathrm{g} \mathrm{P} \mathrm{g} \mathrm{g}^{-1} \mathrm{DS}$ ), control (109 $\left.\mathrm{g} \mathrm{P} \mathrm{g}^{-1} \mathrm{DS}\right)$, and vinasse (64 $\mathrm{g} \mathrm{P} \mathrm{g}^{-1}$ DS). Filter cake treated soil was the only treatment that differed significantly from all others in its phosphorus content (Figure 3c).

\section{Discussion}

In this study, we compared four different crop rotations for sugarcane production that were treated with quite different fertilization methods. The area that was fertilized with filter cake displayed the highest concentrations of organic matter, microbial biomass, respiratory activity, and concentrations of ammonium, nitrate, and phosphorus (Figures 1a, 2a, 2b, 3a, 3b, and $3 c$ ). The results also show that filter cake strongly influences microbial activity. Previous studies have shown that such changes can improve nutrient cycling, making nutrients more available to plants (Hungria et al., 2009).

The chemical analysis revealed that the areas differed significantly from each other in terms of organic matter, $\mathrm{P}$ content, sum of bases, $\mathrm{Mg}^{2+}$ content, and cation exchange capacity. However, there was no statistically significant differences in the soil fertility among the four sites (Table 1).
Total bacteria numbers did not differ statistically between areas (Figure 1c) probably because the addition of vinasse and filter cake benefits the development of some microbial populations and harms others. YanCheng (2009) reported the use of wastes as fertilizers allowed changes in microbial populations but did not result in measurable population increases. On the other hand, bacteria from roots, stems, and leaves of sugarcane increased when compared with conventional fertilization. In that study they did not measure bacteria from soil.

The $\mathrm{P}$ concentration was highest for the filter cake area. It can be surmised that the high $P$ content from filter cake has been transferred into soil. Prado et al. (2013) report that filter cake has great potential for agriculture use. Filter cake has been utilized with good results as a substitute for phosphate mineral fertilizers in field crop production.

In this study the vinasse area presented the highest moisture content compared to the control area (Figure 1b). This would be a consequence of its composition, which consists of basically water (93\%), organic solids, and mineral nutrients. The use of vinasse is beneficial to cane yields in short and longterms although this was not seen in this study. Resende et al. (2006) analyzed soil samples collected from commercial plantations that received vinasse $\left(80 \mathrm{~m}^{3} \mathrm{ha}^{-1} \mathrm{crop}^{-1}\right)$ during 16 years. The data from that study showed that vinasse applications increased mean cane and sugar yield by $12 \%$ to $13 \%$. The yield response in that study was likely due mainly to its high $\mathrm{K}$ content together with the alleviation of soil acidity and Al toxicity. While we did not get such increases in the first year in this study the results do indicate that vinasse and bagasse will not harm the productivity of sugarcane. The cost for vinasse application is more expensive than $\mathrm{K}$ fertilizer and usually cane fields 
nearby distilleries are saturated with K. There should be some consideration paid to the fact that excessive use of vinasse can cause leaching of nitrate and potassium and potential contamination of subterranean waters (Prado et al., 2013).

The lowest respiratory activity occurred in the soybean area compared to the other areas (Figure $2 \mathrm{~b}$ ). This situation provides evidence of low microbial activity and soil depletion. Probably it occurred because the use of soybeans as crop rotation occurred after five years of consecutive sugarcane cultivation.

Even though the sugarcane filter cake showed better conditions for microbial activity compared to other areas, regarding the majority of soil parameters analyzed its use can cause some problems as addition of sugarcane filter cake to moderately acidic and also to alkaline soils led to immobilization of inorganic $\mathrm{N}$ (Khan et al., 2008). Understanding the mode of action of amendments is essential for the improvement of their effectiveness and assimilation into crop systems (Lazarovits et al., 2001). If the amendments improve the establishment of $\mathrm{P}$ solubilizing bacteria as well as the availability of $P$ nutrient to plants, it should be possible to reduce the amount of $P$ fertilizers used in the sugarcane crop.

The number of $\mathrm{P}$ solubilizing bacteria was highest for soybeans, however the result was not statistically different when comparing all the soil treatments. This indicates that none of the fertilization methods allowed a better establishment of these bacteria in the soils. Considerable populations of phosphate-solubilizing bacteria in the soil and in plants may occur in rhizospheres (Rodrigues \& Fraga, 1999). However, this association between plants and microorganisms will occur whenever necessary and also when the environmental conditions provide it.

As the filter cake area presented the highest phosphorus concentration compared with other methods, our hypothesis was that the number of $P$ solubilizing bacteria would be higher than in control, vinasse, and soybean areas. However, surprisingly the number of $P$ solubilizing bacteria was not statistically different between areas. This may be because the high availability of $\mathrm{P}$ nutrient does not allow the association between plants and $P$ solubilizing bacteria. It is the plant that selects the microbial population and when the plant has nutrient availability it does not depend on solubilizers.

In this study we have shown that sugarcane filter cake and vinasse use improves soil microbiology and some soil parameters, but does not improve the establishment of $P$ solubilizing bacteria in soil. While we did not see an improvement in yields of sugarcane in the current crop nutrients released from the applied organic

\section{Acknowledgements}

We would like to thanks Fapesp by financial support process number 2014/18313-8.

\section{References}

Adorna JC, Crusciol CAC, Rossato OB (2013) Fertilization with filter cake and micronutrients in plant cane. Revista Brasileira de Ciencia do Solo 37:649-657.

Bunt JS, Rovira AD (1955) Microbiological studies of some subantarctic soils. Journal of Soil Science 6:119-128.

Camargo JA, Pereira N, Cabello PR, Teran FJ (2009) Viabilidade da aplicação do método respirométrico de Bartha para a análise da atividade microbiana de solos sob aplicação de vinhaça. Engenharia Ambiental 6(2):264-271.

Christofoletti CA, Escher JP, Correia JE, Marinho JFU, Fontanetti CS (2013) Sugarcane vinasse: environmental implications of its use. Waste Management 33:2752-2761.

Hungria M, Franchini JC, Brandão-Junior O, Kaschuk G, Souza RA (2009) Soil microbial activity and crop sustainability in a long-term experiment with three soiltillage and two crop-rotation systems. Applied Soil Ecology 42:288-296.

Keeney DR, Nelson DW (1982) Nitrogen-inorganic forms. Methods of soil analysis Part 2 Chemical and microbiological properties 643-698.

Khan KS, Gattinger A, Buegger F, Schloter M, Joergensen RG (2008) Microbial use of organic amendments in saline soils monitored by changes in the $13 \mathrm{C} / 12 \mathrm{C}$ ratio. Soil Biological and Biochemistry 40:1217-1224.

Laime EMO, Fernandes DCS, Freire EA (2011) Possibilidades tecnológicas para a destinação da vinhaça: uma revisão. Revista Trópica: Ciências. Agrarias e Biologicas 5:86-90.

Lazarovits G, Tenuta M, Conn KL (2001) Organic amendments as a disease control strategy for soilborne diseases of high-value agricultural crops. Australian Plant Pathology 30:111-117.

Mendonça E de S (2005) Matéria orgânica do solo: métodos de análises. 107p. (UFV).

Olsen SR, Sommers LE, (1982) Methods of soil analysis. Part 2. Agronomy Monography 403-430.

Prado R de M, Caione G, Campos CNS (2013) Filter cake and vinasse as fertilizers contributing to conservation agriculture. Applied Environmental Soil Science 1:1-8. 
Pupin B, Nahas E (2011) Impact of successive sugarcane harvests and trash management practices on soil microbiological properties. Soil Respiratory 49:183-189.

Resende AS de, Santos A, Xavier RP, Coelho $\mathrm{CH}$, Gondim A, Oliveira OC, Alves BJR, Boddey RM, Urquiaga S (2006) Efeito da queima da palhada da cana-de-açúcar e de aplicações de vinhaça e adubo nitrogenado em características tecnológicas da cultura. Revista Brasileira de Ciência do Solo 30:937-941.

Rodriguez H, Fraga R (1999a) Phosphate solubilizing bacteria and their role in plant growth promotion. Biotechnology Advance 17:319-339.
Sims JR, Haby VA (1971) Simplified colorimetric determination of soil organic matter. Soil Science 112:137-141.

Watanabe FS, Olsen SR (1965) Test of an ascorbic acid method for determining phosphorus in water and $\mathrm{NaHCO} 3$ extracts from soil. Soil Science Society of American Journal 29:677-678.

YanCheng M, QiZhan T, Zhong L, GuiFen C, Ying W, others (2009a) Impact of several organic materials of sugar industry on soil microbe population in sugarcane field. Southwest China Journal of Agriculture Sciences 22:389-392. 